\title{
Educational Values In Hujan By Tere Liye As A Literary Teaching Material In Senior High School
}

\author{
Ediwarman, Dase Erwin Juansah, Asep Muhyidin, Aisyah Hamidiyah \\ University of Sultan Ageng Tirtayasa \\ datuk@untirta.ac.id
}

\begin{abstract}
This study aimed to gain a deep understanding towards the values of education in Tere Liye's novel, Hujan. The source of research data was a novel by Tere Liye, Hujan. The data of the research were educational values contained in the novel. Descriptive qualitative used as the method of the research. The study found that Tere Liye's novel Hujan reflects the educational values for his readers: first, the moral value of education: always help, perseverance, and responsibility. Second, the value of social education: humanity, caring, and empathy. Third, the value of cultural education: mutual cooperation, obedient rules, and mutual respect. It was suggested that Tere Liye's Hujan can be selected as an alternative to literary teaching materials in high school.
\end{abstract}

Keywords-Educational values; Hujan novel; and teaching materials

\section{INTRODUCTION}

In the world of education, literary learning is very important to give to students. A teacher should be able to plan and implement teaching in school. Therefore, teachers are expected to have the ability to educate and teach students to be smart and have goals. Indonesian Language and Literature Education is one of the subjects that can shape and build the character of students. One of Indonesian language and literature material learning that is able to build the character of the students is literary works, especially novels. The presence of a novel can affect the attitudes and behavior of its readers.

According to Hasanudin (2007) a novel is defined as a long prose that presents characters, displays a series of events, and settings chronologically. A novel is usually longer and more complex than a short story, generally a novel tells a story of characters in everyday life. A novel reveals deep human aspects of life, for example by describing human suffering, struggle, affection, or hatred. Reading a novel has a specific purpose, not only for entertainment but also can broaden the readers' knowledge. Novels are a means of the author to devote ideas, thoughts, and feelings through writing, thus novels can be used as a means of learning by the author, as in the novel Hujan.

Based on researchers' observations and experience, Literary learning in schools was not maximally achieving the objectives in accordance with the standard content's indicators. This causally relates to the teachers' strategies, methods, and learning resources used did not lead to comprehension. Therefore, the author chose the novel Hujan by Tere Liye because the novel is very inspiring to the reader. In addition, literary learning in high school generally focuses only on intrinsic element analysis. In fact, the extrinsic element is also very important to teach to understand about the values of life that benefit the students. As it is important for students, the researchers consider it necessary to conduct an analysis of the values of education in Tere Liye's novel Hujan.

The researchers were interested to analyze the values of education in the novel "Hujan" to find the values of education in the novel and the suitability of the novel to be used as a material for literary teaching in high school. Tere Liye's novel Hujan is the latest and best-selling novel. This novel was published in January of 2016. The novel tells about two teenagers who both experienced a terrible earthquake. They accidentally meet to save themselves when the earthquake happens. After the earthquake, they live in a shelter and must be able to stand alone to live a life. They fight vigorously to achieve their goals. They teach us to struggle in a difficult situation. In addition, they also teach us not to give up easily achieving goals.

Based on the various problems in the literature teaching in high schools, especially novel learning, this research is focused on the values of education in Tere Liye's Novel Hujan. The subfocus in this study are as follows. (1) An analysis of the values of education contained in the novel Hujan by Tere Liye, and (2) Novel Hujan by Tere Liye used as a literary material in high school.

Intrinsic and extrinsic approaches are used in reviewing a novel. Extrinsic approach was used in this study. Extrinsic elements are elements that are outside the literary work, but indirectly affect the building or system of the organization. More specifically, these elements affect the story of a literary work, but do not take part of the literary work. 
Extrinsic elements of the novel are the educational background of the author, social conditions of society, customs of certain areas, and so forth. Meanwhile, according to Nugiyantoro (2012) research on extrinsic elements in a novel has been done by researchers. Widyahening \& Nugraheni (2016) studied character education and literary appreciation. Simanjuntak, Siburian, \& Saragi (2017) conducted a research on the value of character education in a novel entitled Habibie and Ainun, the study revealed the most dominant character value of education is the value of tolerance and the value of love homeland. In addition, Efendi \& Muttaqien (2017) studied the value of education in Malay folklore "Hikayat Hang Tuah". Emi (2017) examines the moral and cultural values in a novel entitled "Kelopak Cinta Kelabu" by Suhairi Rachmad and its implication in literary appreciation learning in Junior High School. Fitriati (2015) examines the values of education in a novel "Sang Pemimpi" by Andrea Hirata. The prominent educational values in the novel include moral, religious, beauty, and truth.

\section{METHODS}

The method in this research is qualitative method. Qualitative research is a set of scientific procedures that can be used to solve problems in accordance with the point of view and the approach used by researchers. According to Moleong (2014) qualitative research methods is a research that intends to understand the phenomenon in the natural research subjects such as behavior, perception, action and others. Descriptive research design was used in this study as it tried to describe the event that happened at the time of this research executed or trying to describe what existence of a symptom or circumstance. Best (in Sukardi, 2008) states that descriptive research is a research method that seeks to describe and interpret objects as they are. In addition, this study used a qualitative approach. The subject of the research is a novel by Tere Liye Hujan, while the object of the research is the values of education contained in the novel.

Data collection method is the most important step in the research because the main purpose of research is to collect data Sugiyono (2009). Data collection method used in this research is documentation method. It is used to obtain data sourced in writing, such as books, magazines, documents, regulations, and so forth Arikunto (2005). In this research, educational values in Tere Liye's novel were obtained. To gain the data, the researchers recorded the data that are considered to the values of education into the data card as the instrument. The data then was analyzed using descriptive qualitative analysis method and following suggested procedure; data reduction, data display, and data conclusion.

\section{The Values of Education in Tere Liye's Novel}

\section{FINDING AND DISCUSSION}

Before researchers further examined the values of education in the novel Hujan by Tere Liye, researchers first analyzed the element of the novel using the theory of Robert Stanton. Stanton (2007), distinguishes the element of a novel into three parts: theme, fact of story, and means of literature. The analysis of the element of the novel by Tere Liye, is as follows. First, the theme of the novel was telling the fight for happiness. Secondly, the facts of the story are as follows: a) a backward plot because the narrative is not ordered, b) the main character is Lail, Esok, Maryam, and Elijah. Third, the setting of place is dominated in the refuge, the time background is in the morning, afternoon, and evening, and the social setting relates to the sad atmosphere of earthquake victims.

\subsubsection{Moral Education Value}

Moral, as interpreted by Suseno (2001), is a word that refers to the good and bad side of human as human, so that the moral field is the field of human life viewed in terms of goodness as a human being. Moral is the doctrine of the good and the bad related to the deeds, attitudes, obligations and so on. Moral is also called good characters and ethic. Helpful habit is a behavior that can be developed by always ready to help and actively seek opportunities to contribute. The value of being helpful in the novel follows.

"Esok dengan sabar membantu Lail melewati hambatan di jalan, memegangi tangannya saat memanjat reruntuhan, menjaganya, dan memastikan Lail baik-baik saja" Esok patiently helped Lail through the roadblocks, holding her hands as she climbed the ruins, guarding them, and making sure Lail was fine"

Perseverance and commitment is a good moral education to form a positive mental. Commitment makes a person stand in achieving the ideals, the work of someone and others. Commitment is a pledge that is firmly held to belief, support and faithful to family and friends. The value of perseverance in the novel showed up on Lail's character who struggles to become a volunteer officer, struggling to organize his heart to forget Esok to erase all his memories. Here's the quote.

"Sepuluh meter maju, kubangan lumpur sudah setinggi dada. Maryam mengigit bibirnya, dengan tekad tokoh dia terus maju. Di belakang, gerakan Lail lebih lambat, kakinya sudah berat dilangkahkan" Ten meters forward, the mud puddles are already at chest level. Maryam bit her lip, with she continues heroically. At the back, Lail's movement is getting slower, his legs are heavily stepped up" 
Responsibility is the human consciousness of deliberate or unintentional behavior. Responsibility also means acting as the embodiment of awareness of obligations. Responsibility is a behavior that determines a person's reaction to everyday situations that require some decisions (Shchiller \& Tamera, 2002)

"Mereka berhasil melewati kubangan lumpur. Perkampungan penduduk sudah dekat, mereka bisa mengantar peralatan medis dan obat-obatan di lokasi bencana" They got through the mud puddles. The residents' settlements are near; they can deliver medical equipment and medicines at the disaster site.

The moral value aims to educate people to know the values of ethics, for it is the value of a good or bad behavior, what to avoid and what to do, to create a human relationships in a society that is considered good, harmonious, and beneficial to people, society, environment, and nature. Moral relates to the noble nature of humans, fight for human rights and dignity. This moral value is more related to the behavior of our daily lives. It can be said that the value of moral education shows the rules of behavior and customs of an individual of a group. Anindyarini (2017) stated that moral values are expected to bring change from the less good to the good, from the less responsible to be responsible. In principle, today must be better than yesterday and tomorrow must be better than today.

\subsubsection{The Value of Social Education}

Social value refers to the relationships of individuals with other individuals in a society. How one should behave, how they solve problems, and deal with certain situations are also included in social values. Uzey (2009) argues that social value refers to the consideration of an act of things, the way to decide whether the valuable thing has the truth, beauty, and divine value.

Social value can be summed up as a collection of attitudes and feelings manifested through behaviors that influence the person's behavior. Social values are attitudes and feelings that are widely accepted by society and are the basis for formulating what is right and what is important.

The social value in "Hujan" appears to Lail and Maryam as a volunteer. They were fighting for humanity therefore their struggles got satisfactory results and were awarded by government. The quote is below:

"Saat Maryam mencoba meyakinkan petugas agar mengizinkan Maryam dan Lail mengikuti seleksi rekrutmen relawan baru, "Kami berdua bosan hanya mengikuti kursus memasak di panti sosial, menghias kue-kue. Bosan tidak melakukan apa pun, sementara orang lain membantu banyak. Kami bosan hanya menjadi remaja biasa-biasa saja. Kami memang tidak genius, tidak bisa membuat mesin roket, atau memiliki bakat hebat, tapi kami ingin membantu. Ini situasi yang amat khusus" (Liye, 2016)"

"When Maryam tried to convince the officer to allow Maryam and Lail to register a new volunteer recruitment selection, "We're both tired of just taking a cooking course at a social home, decorating cakes. We are bored for not doing anything, while others help a lot. We are tired of just being ordinary teenagers. We are not geniuses, we cannot make rocket engines, or have great talent, but we want to help. This is a very special situation "(Liye, 2016)"

Social means matters pertaining to society or public interest. People empathize with everyone who is affected by a disaster such as earthquakes. The value of social education is a lesson that can be derived from social behavior and social life. Social behavior in the form of a person's attitude towards events that occur around him that has to do with other people, ways of thinking, and social relationships between individuals. The value of social education will make people aware of the importance of group life in the bonds of kinship between one individual with another individual. The occurrence of awareness among the community includes something that goes into the realm of social values. The value of social education refers to the relationships of individuals with other individuals in a society. How one should behave, how they solve problems, and deal with certain situations are also included in social values.

\subsubsection{The Value of Cultural Education}

Cultural value according to Rusyana (2002) is something that is considered good and valuable by a group of people or tribes that would not necessarily be viewed well by other groups or ethnic groups because of cultural values limit and provide characteristics to a society and culture. Koentjaraningrat (1987: 85) stated that cultural value consists of conceptions that live in the minds of most citizens about things that they consider very noble. In society, this value system is concerned with human attitudes and behavior. The value system is an integral part of the moral ethics described in social norms, legal systems and customs that serve as a set of rules for governing society. According to Kluchohn in Koentjaraningrat (1987), each system of cultural values in each culture contains five basic problems in human life. The five basic problems are (1) human relationships with oneself, (2) human relationships with human beings, (3) human relationships with society, (4) human relationships with nature and (5) human relationships with God. 
"Di panti sosial ada banyak jadwal dan peraturan yang harus dipatuhi. Jangan coba-coba melanggar, atau bersiaplah menerima jenis hukuman memalukan. (Liye, 2016: 80). "pukul enam, semua penghuni panti harus sudah berada di ruang makan besar dengan pakaian rapi, duduk di hadapan meja-meja besar" (Liye, 2016)"

"There are many schedules and rules that must be obeyed in social house. Do not try to break, or you'll get shameful punishment. (Liye, 2016). "At six o'clock, all members must be in the dining room in neat clothes and sitting in front of large tables" (Liye, 2016).

Cultural values embedded in the community environment as the background of the novel "Hujan" was still clearly visible when they work together in community activities. One of them was cooperation in social house. The culture of obeying the rules was evident when someone breaking the rules would face punishment. Culture was still attached to the motto of togetherness. While in the educational environment, especially in schools, the students were used to follow the rules. Culture of respecting others was still felt in the territory of the state of Indonesia.

\section{Criteria of Suitability to Literature Learning Materials in Senior High School}

Learning materials is one of elements in teaching and learning activities that are used to facilitate teachers in carrying out teaching activities and help students in learning to make interesting learning process. In teaching novels, teachers should be skilled and meticulous in choosing the appropriate novels for the students and their times. Thus, the learning material is the most important part in the learning process. Therefore, the selection of learning materials requires careful preparation and consideration.

Various learning materials provide alternatives for teachers to choose approaches and ways of teaching that can achieve effective learning objectives. A teacher must be able to alleviate learning to fit the expected learning objectives. For that, teachers should be able to choose the learning materials in accordance with the ability of students.

One of aspects of literary material is novel learning. The position of novels in literary materials is to make students involved and have sensitivity to the material presented. The researcher chose Tere Liye's novel "Hujan" because the researcher is interested in the characters and the story. The author presented a world of human psychology. Literature has a primary function as a refinement, increasing sensitivity, sense of humanity, social concerns, growing cultural appreciation, distributing ideas, imagination, and creative and constructive expression both orally and in writing. Through literature, students are invited to understand and appreciate literary works.

The purpose of literary learning in high school was that the students were able to have the following abilities. (1) Understand and utilize literary works to develop personality, broaden the horizon of life, and improve the knowledge and language skills; (2) Express the medium of literature; and (3) Appreciate and be proud of Indonesian literature as cultural and intellectual treasury of Indonesian.

The objectives of Literary learning is that basically students have sensitive feeling to valuable literary works thus they feel encouraged and interested to read. By reading literature, it is hoped that students will gain a good understanding about humanity, values and new ideas. Literary learning, especially novels, functions to foster a sense of awareness. Tere Liye's novel "Hujan" can certainly help, support, and enrich the reading materials in teaching literature.

The existence of novels in literary learning opens new enlightenments to students to be more active and constructive to today situations. The novel "Hujan" contained positive things that teach the reader to struggle, to be brave facing problems in life, achieve goals, foster moral attitude, social, and be more independent. Those values appeared on Lail, Esok, and Maryam.

\section{SUMMARY}

Based on the findings and discussion, it can be concluded that this novel is themed about the struggle of life. Tere Liye's novel entitled "Hujan" can be used as an alternative to literary materials in high school. This novel contained good educational values to be used as teaching materials in learning literature. Teachers are expected to create an interesting and fun learning literature process thus both literary materials and the teaching strategy would be qualified. Students should increase the interest in appreciating literature for they are more critical in assessing the work of literatures. Other researchers were suggested to use different literary approaches to study Tere Liye's novel "Hujan". It is expected that the results of this study can be useful as a reference for other researchers who will examine the works of literature from the extrinsic element point.

\section{References}

Anindyarini, A. (2017). Moral Value or Characters in Fantasy Story. Advances in Social Science Education and Humanities Research, 122-129, Vol 156.

Arikunto, S. (2005). Manajemen penelitian. Jakarta: Rineka Cipta. 
Efendi, A. N., \& Muttaqien, M. (2017). Educational Values in Hikayat Hang Tuah Malay Folktale Lekksema. Jurnal Bahasa dan Sastra, 131-143, Vol 2 No 2.

Emi. (2017). Nilai Moral dan Budaya dalam Novel Kelopak Cinta Kelabu Karya Suhairi Rachmad dan Implikasinya dalam Pembelajaran Apresiasi Sastra di SMP. Jurnal Pembelajaran Bahasa dan Sastra Indonesia, 69-84, Vol 7 No 1.

Fitriati, S. (2015). Nilai-nilai Pendidikan Novel Sang Pemimpi Karya Andrea Hirata. Jurnal Pesona, 104-116, Vol 1 No 2.

Hasanudin, WS. (2007). Educational values. Bandung: Titian Ilmu.

Koentjaraningrat. (1987). Manusia dan kebudayaan di indonesia. Yogyakarta: Djambatan.

Moleong, L. (2014). Metodologi penelitian kualitatif. Bandung: Remaja Rosda Karya.

Nugiyantoro, B. (2012). Teori pengkajian fiksi. Yogyakarta: Gadjah Mada University Press.

Rusyana, Y. (2002). Metode pengajaran sastra, edisi ketiga. Bandung: Angkasa.

Shchiller, P., \& Tamera, B. (2002). 16 Moral dasar bagi anak. Jakarta: Alexedia Komputindo.

Simanjuntak, M., Siburian, T. A., \& Saragi, D. (2017). An Analysis of Character Education Values in Non-Fiction Novel "Habibie dan Ainun" and Its Advantages as Literature Reading for Senior High School in Medan Indonesia. British Journal of Education, 29-49, Vol 5 No 11.

Stanton, R. (2007). Teori fiksi. Yogyakarta: Pustaka Belajar.

Sugiyono. (2009). Metode penelitian pendidikan (pendekatan kuantitatif, kualitatif dan $r \& d$. Bandung: Alfabeta.

Sukardi. (2008). Metode penelitian pendidikan (kompetensi dan praktiknya). Yogyakarta: PT Bumi Aksara.

Suseno, F. (2001). Model pendekatan etika. Yogyakarta: Kanisius.

Uzey. (2009). Nilai moral dalam teori sastra. Jakarta: PT Grasindo.

Widyahening, E., \& Nugraheni, E. W. (2016). Literacy Works and Character Education. International Journal of Language and Literature, 4(1), 176-180, 